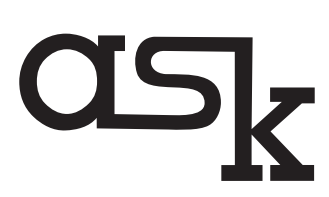

Research \& Methods ISSN 1234-9224, e-ISSN 2544-0799 Vol. 27 (1, 2018): 61-86 The Ohio State University Libraries Columbus, Ohio, USA Institute of Philosophy and Sociology Polish Academy of Sciences, Warsaw, Poland www.askresearchandmethods.org DOI: 10.18061/ask.v27i1.0004

\title{
Political Participation and Institutional Trust of Young Adults in Ukraine: Matching Economic and Political Conditions with European Social Survey Fieldwork Periods, 2004-2012
}

\author{
Viktoriia Muliavka \\ Institute of Philosophy and Sociology, Polish Academy of Sciences
}

\begin{abstract}
Whereas economic grievance and the political opportunity structure could be the basis for understanding Ukrainian youth political participation and institutional trust, to date, no one has systematically applied the necessary contextual information to survey data to make this claim. To study these topics with survey data, we would need to match this context to the specific fieldwork periods in which the survey data was collected. In this article, I match the economic and political situations of young adults in Ukraine with the fieldwork periods of the European Social Survey (ESS) from 2004 to 2012. This facilitates the use of ESS to test theories of grievance and political opportunity structure. I found that periods of economic grievance do not neatly align with trends in participation and trust. The possibility is open for the continual low participation and trust to be associated with the political opportunity structure provided predominantly by political parties during mass uprisings.
\end{abstract}

Keywords: political participation, institutional trust, youth, economic grievance, political opportunity structure

\section{Acknowledgements}

This research was funded in part by the National Science Centre, Poland (project number 2016/23/B/HS6/03916). Versions of this research was presented at First Annual International Conference on Public Policy 'Public Policy in the Post-Soviet Context: Institutions, Ideas and Societies' at the Department of Comparative Political Studies North-West Institute of Management RANEPRA (St.-Petersburg, Russia, March 2018), 1st ECPR/ODIHR Summer School on Political Parties and Democracy, OSCE Office for Democratic Institutions and 
Human Rights (ODIHR) (Warsaw, Poland, July 2018) and Berlin Summer School in Social Sciences 'Linking Theory and Empirical Research', Berlin Graduate School of Social Sciences (Berlin, Germany, July 2018). I am grateful for the comments from Joshua K. Dubrow, Fernando Casal Bértoa, Katarzyna Grzybowska-Walecka, and Diana Burlacu.

Ukrainian youth today started their adult lives in independent states that began to transform its institutions from centrally-planned state socialism to capitalism. The shift had resulted in an initial sharp economic downturn, volatility in the region, cuts to welfare expenditures, and rising poverty and economic inequality (Böröcz 2012). During this time, the youth have suffered tremendously from the impacts of neoliberal economic transformation ranging from budget cuts on educational and social welfare spending to limited labour market access for university graduates (Bojcun 2011). The political context during post-socialist transformations was unstable. There have been several political upheavals, including the Orange Revolution, turn on Western orientations in domestic and external policies afterwards, and the return of strong Russian influence during the Yanokovych regime. After the return of Yanokovych, there has been Euromaidan, a change in government, the annexation of Crimea, and a military conflict in Ukraine.

Some theorists associate the combination of economic restructuring that leaves the youth and other disadvantaged groups in greater peril of precarious and unstable employment and the constantly shifting political context with low political participation and institutional trust in the region (Karakoc 2013; Vrablikova 2014). Post-socialist states tend to have lower levels of political participation and trust in institutions than the Western established democracies (Teorell et al. 2007; Karakoc 2013) and trust toward government institutions and formal organisations have dramatically declined during post-socialist transformations (Pehlivanova 2009 p.32). In Eastern Europe, non-institutionalized participation (such as consumer participation, protest activity, and contacting officials) is linked to political parties that act as a mobilizing force (Teorell et al. 2007).

Economic grievance and political opportunity structure could be the basis for understanding of Ukrainian youth political participation and institutional trust, but to date, no one has systematically applied the necessary contextual information to make this claim. To study these topics with survey data, we would need to map this context to the specific fieldwork periods in which the survey data was collected.

In this article, I present the socio-economic and political context for European Social Survey (ESS) data 2004-2012, in which Ukraine participates in all rounds. How does this context, as it relates to young adults in Ukraine, correspond with the ESS fieldwork periods? Addressing this research question better enables scholars to test the explanatory power of grievance theory and political opportunity structure 
Viktoriia Muliavka, Political Participation and Institutional Trust of Young Adults in Ukraine: Matching Economic and Political Conditions with European Social Survey Fieldwork

Periods, 2004-2012

models in the context of youth political participation and trust in Ukraine. This is a mixed methods study. After presenting the contexts, I use ESS data to analyze trends in participation and trust of Ukrainian youth. I intend for this presentation of context and trends during fieldwork periods to facilitate the use of ESS to test theories of grievance and political opportunity structure.

\section{ESS Fieldwork Periods for Ukraine}

Statistical analysis of surveys provides substantial basis for generalization, however, this data is limited for understanding specific events and processes. Apart from these general limitations, it is important to check methodological details thoroughly before performing of any statistical analysis as misuse of the data could lead to distorted research conclusions. Particularly, as I found in ESS, official dates of survey waves could not correspond with the dates of fieldwork periods in certain countries. In this regard, using ESS I locate the respondents' attitudes and behaviours within the fieldwork period which, at times, differ from the official date of the ESS survey. Everyday users of ESS data for Ukraine may not consider this issue enough to check if the official date of the data matches when the data was reported. Thus, they may not understand the exact context in which the data were collected. I assume that the context of the fieldwork is a primary influence of how the respondents will answer the survey questions. The dates of fieldwork in Ukraine are presented in the Table 1.

Table 1. Targeted and Actual Fieldwork Periods of European Social Survey in Ukraine

\begin{tabular}{|c|c|c|c|}
\hline $\begin{array}{l}\text { Ukraine appears } \\
\text { in Round... }\end{array}$ & $\begin{array}{l}\text { The official date } \\
\text { of the data is... }\end{array}$ & $\begin{array}{l}\text { Targeted Fieldwork Period } \\
\text { of ESS as a whole... }\end{array}$ & $\begin{array}{l}\text { The actual fieldwork period } \\
\text { for ESS Ukraine was... }\end{array}$ \\
\hline 2 & 2004 & $\begin{array}{l}\text { September 1, } 2004- \\
\text { December 21, } 2004\end{array}$ & $\begin{array}{l}\text { January 28, } 2005- \\
\text { March 10, } 2005\end{array}$ \\
\hline 3 & 2006 & $\begin{array}{l}\text { September 1, } 2006- \\
\text { December 21, } 2006\end{array}$ & $\begin{array}{l}\text { December 6, } 2006- \\
\text { January 12, } 2007\end{array}$ \\
\hline 4 & 2008 & $\begin{array}{l}\text { September 1, } 2008- \\
\text { December 21, } 2008\end{array}$ & $\begin{array}{l}\text { March 1, } 2009- \\
\text { April 2, } 2009\end{array}$ \\
\hline 5 & 2010 & $\begin{array}{l}\text { September 1, } 2010- \\
\text { December 21, } 2010\end{array}$ & $\begin{array}{l}\text { May } 13,2011- \\
\text { July } 30,2011\end{array}$ \\
\hline 6 & 2012 & $\begin{array}{l}\text { September 1, } 2012- \\
\text { December 21, } 2012\end{array}$ & $\begin{array}{l}\text { July } 11,2013- \\
\text { August } 9,2013\end{array}$ \\
\hline
\end{tabular}

Note: From the European Social Survey website, found in the pages for "Fieldwork Summary and Deviations". Accessed August 2018: https://web.archive.org/web/20180201234934/http://www.europeansocialsurvey.org/ data/deviations_index.html 
Fieldwork periods are typically one year after the official dates of the surveys. For example, the 2004 data was collected in 2005, and some of the 2006 data was collected in 2007, and so on.

\section{THEORETICAL BACKGROUND}

Political participation can be defined as action by ordinary citizens directed toward influencing some political outcomes (Teorell et al. 2007). Teorell (2006) defines three different conceptions of political participation: influencing attempts that aim to insure equal protection of interests; direct decision making resulting in selfdevelopment and political discussion that results in subjective legitimacy. In this article I focus on the conception of influencing attempts in operationalization of political participation.

Political trust can be conceptualized as a general assessment by citizens of the extent to which actors and institutions within the political system behave according to citizens' expectations (Hooghe \& Kern 2015). Post-socialist states have the lowest levels of political trust (e.g. trust in country's parliament, trust in the legal system, trust in the police, trust in politicians) in Europe (Hooghe \& Kern 2015).

\section{Youth Political Participation and Institutional Trust}

To empirically analyze youth participation and trust using ESS data, quantitative scholars must define this category with numbers. Defining the age interval for operationalization of "youth cohort" varies greatly from one research paper to another with three main approaches: generational, empirical, and sociocultural. Each depend on the methodology and purpose of research. According to a generational approach, researchers compare age cohorts who were born and socialised in different political and economic contexts. Foa and Munk (2016) define the millennial generation as born in 1980 and compares them to their babyboomer parents who were born during the first two decades after the Second World War. Researchers that analyze changes to the civic and political participation of young people also emphasize the generational aspect. Usually defined as under 30 years of age, young generation has many names: "Post-9/11 Generation", the "Millennials", or the "DotNets" (Fisher 2012).

The empirical approach to defining age brackets depends on selected indicators of political participation. In research papers comparing age cohorts by voting behaviour, the lower end of the youth age bracket is 18 (McFarland \& Thomas 2006, Carpini 2000, Hart \& Hen 2017). Research papers analysing youth activism and participation in voluntary organizations define age brackets based on the 
Viktoriia Muliavka, Political Participation and Institutional Trust of Young Adults in Ukraine: Matching Economic and Political Conditions with European Social Survey Fieldwork Periods, 2004-2012

average membership age of organizations under study (McFarland \& Thomas 2006, Smith 1999, Quintellier 2008). Longitudinal data present an opportunity to follow the respondent's trajectories from before 18 (Smith 1999). The sociocultural approach is based on the idea that 'youth' is social construct and identification of person as young depends on the specific context. This approach is more common for qualitative studies. For example, Rossi (2009) in his case study of ATTAC (Argentina), the Klampun Community of Papua New Guinea, and the World YWCA, and Fisher (2012) in her analysis of cases of Obama campaign 2012 election in US do not strictly define age brackets of their respondents. Considering this discrepancy in operationalization of youth and the fact that I use different sources of data in this paper (survey data, statistical data, protest event data and secondary sources), there are some inconsistencies in age brackets according to methodological limitations.

Concept of political participation is operationalized through both institutionalized or conventional (electoral) and non-institutionalized or non-conventional (nonelectoral) forms of participation (Teorell et al 2007, Marien et al 2010, Hooghe, $\&$ Kern 2015). In research on youth political participation conducted in US and Western Europe, there is a trend of young people rejecting electoral politics and disengaging from public life (Melo \& Stockemer 2014; Delli Carpini 2000; Earl et al. 2017). The literature classifies explanations for this tendency into individual social background and structural factors. In the literature socio-economic background and family practices are defined as an independent factor of influence on youth political participation (Melo \& Stockemer 2014) or mediating factor that influence on participation in voluntary organizations (McFarland \& Thomas 2006). From structural perspective, youth become less politically active and more vulnerable category of society in the context of neoliberal policies (Hart and Henn 2017).

In literature, the youth have been portrayed as apathetic, distrustful and unsupportive of democratic institutions, and uninterested in public affairs (Albacete 2014). Some argue that youth political participation is changing rather than declining. According to Earl et al. (2017) young people are politically active and involved in their own political socialization as evident when examining noninstitutionalized political participation, e.g. protest and other forms of participatory politics. According to Hart and Henn (2017) and Melo and Stockemer (2014), while their older contemporaries have maintained engagement with formal politics, today's young are practicing alternative politics, or what Marien et al (2010) referred to as non-institutional participation. Individuals born between the late 1970s and early 1990s are significantly more likely to engage in forms of direct action, such as demonstrations and petitions. 


\section{Grievance Theory}

According to grievance theory, deprivation and grievances stimulate political participation and protest behavior particularly (Gamson 1968; Wilkes 2004). In his casual model of strife, Gurr (1968) examined 114 polities and proposed a psychological variable of relative deprivation as the basic precondition for the phenomenon. Relative deprivation is defined by Gurr as "'actors' perceptions of discrepancy between their value expectations (the goods and conditions of the life to which they believe they are justifiably entitled) and their value capabilities (the amounts of those goods and conditions that they think they are able to get and keep)" (Gurr 1968: 1104). He defined strife as "collective, nongovernmental attacks on persons or property that occur within the boundaries of an autonomous or colonial political unit" (Gurr 1968: 1107). The more widespread and intense deprivation is among individuals in society, the greater is the magnitude of strife in one or another form.

In his work Gurr (1968) differentiates between persistent and short-term deprivation. Persistent deprivation is operationalized through economic and political discrimination (limiting social group's access to higher economic value positions and opportunities to participate in political activities or to attain elite positions) as well as potential separatism, dependence on private foreign capital, religious cleavages and lack of educational opportunity (Gurr 1968: 1109-1110).

Short-term deprivation was measured through economic conditions such as short-term trends in trade value, inflation, decline in GNP growth, and adverse economic conditions; and through political conditions, such as new restrictions on political participation and representation by the regime, new depriving policies (Gurr 1968: 1111-1112). Scholars had further developed this theoretical model to emphasize that political and economic grievances of deprived individuals and groups are a main impetus for political mobilisation (Wilkes 2004).

Since Gurr, grievance has been operationalized in different ways. Wilkes' (2004) study of First Nation protests in Canada, measured grievance through unemployment, which had a significant influence on collective action. Dalton et al. (2010) with data from 1999-2002 wave of the World Values Survey, operationalised grievance through macro-economic factors (GDP per capita, changes in GDP, level of income inequality) and psychological factors (average life satisfaction, national happiness) (Dalton et al 2010: 64). Ortiz et. al (2013) in their study of 843 protest events in 84 countries during 2006-2013 had defined four main dimensions of sources of grievance: economic justice/anti-austerity, failure of political representation and political systems, global justice and rights of people. According to Ortiz et al (2013), economic justice and anti-austerity are the most numerous type of protests in observed period. Authors emphasise that the 
Viktoriia Muliavka, Political Participation and Institutional Trust of Young Adults in Ukraine: Matching Economic and Political Conditions with European Social Survey Fieldwork Periods, 2004-2012

reason of their acceleration is the contraction of decent jobs as a result of the global crisis and expansion of austerity measures worldwide since 2010. Main categories of economic justice/anti-austerity protests are: reform of public services; pension reform; jobs, higher wages and labour conditions; tax/fiscal justice; inequality; low living standards; agrarian/land reform; fuel/energy prices; food prices and housing. According to the study, among the most important grievances of protests in Ukraine during this period there are protests against pension reform, protests against the North Atlantic Treaty Organization and rights-based protests related to issue of ethnic justice (Ortiz et al 2013).

\section{Political Opportunity Structure (POS)}

Political opportunity structure (POS) theory emphasizes that political opportunities is what facilitates grievances as a factor for mobilization. This theoretical model was developed within resource mobilization tradition, according to which deprivation and associated grievance are relatively constant (Wilkes 2004: 571). As Mayer (2004) argues, the key recognition in the political opportunity perspective is that activists' prospects for advancing particular claims, mobilizing supporters, and affecting influence are context-dependent. Analysts appropriately direct much their attention to the world outside a social movement, on the premise that 'exogenous factors enhance or inhibit a social movement's prospects for mobilization; advancing particular claims rather than others; cultivating some alliance rather than others; employing particular political strategies and tactics rather than others, and affecting mainstream institutional politics and policy' (Mayer 2004: 126). A number of such factors of POS are defined in the literature: traditions and institutions; governmental structure; political stability and openness; public policies and government actions; political discourse; elite alignment (Meyer \& Staggenborg 1996: 1633-1634).

POS link change in protest activity to changes in the resources available to the group or to changes in political opportunities and national conditions (Wilkes 2004: 572). In her study of citizen activism across 24 old and new democracies based on ISSP (2004) data, Vrabikova (2014) argued that in addition to resources, motivations and mobilization, institutional opportunities also facilitate individual participation in non-electoral politics. Citizen activism is expected to increase if opportunities for political participation are open and decrease if citizens believe the opportunities for influencing public decisions as closed. Specifically, Vrablikova (2014) emphasized decentralization of state institutions on the basis of the principle of checks and balances as key influence on individual non-electoral participation. According to her study, decentralization does so because it offers more access points to influence politics and increasing the opportunities for citizens to have an impact on decision-making. In addition, political opportunity structure also plays 
a second role through increasing the mobilizing effect of social networks on nonelectoral participation (Verbikova 2014: 2).

Based on the literature on grievance and POS, there appears to be three main stages of increase in political participation for youth in Ukraine:

(1) Deprivation as disadvantaged status of the youth as a result of elites' economic and/or political decisions.

(2) Grievance - feeling of anger and dissatisfaction as the result of deprivation in socio-economic and/or or political conditions.

(3) Political mobilization - the process of building opportunity structure for political participation that could be grassroots and/or imposed from above (elites could use grievances for stimulation of youth protests in order to satisfy their own political interests).

Thus, the literature suggests that political mobilization could not work without substantial feeling of grievance by deprived individuals or groups; at the same time, grievance could not be transformed into political action without provided political opportunity structure. In light of this, in this article I examine grievance and POS together and across time.

\section{POTENTIAL SOURCES OF ECONOMIC GRIEVANCE AND POLITICAL OPPORTUNITY STRUCTURE FOR UKRAINIAN YOUTH}

In this section I focus on analysis of potential sources of grievance and political opportunity structure for youth political participation in Ukraine during 2004 2013. Analyzing sources of grievance, I consider the economic situation. Political opportunity structure is represented by larger political factors, such as the Orange revolution, party mobilization - interpreted as the actions that political parties take to get people to vote or to otherwise support party goals - and political corruption. Economics and politics are often connected - thus, in each I will occasionally present economic or political indicators, as appropriate.

\section{Economic Context for Youth by ESS Fieldwork Periods}

Based on the previous research (Gurr 1968; Wilkes 2004; Dalton et al 2010 Ortiz et al. 2013, Solt 2015), for the analysis of sources of grievance for Ukrainian youth I use macroeconomic indicators of GDP per capita growth (annual \%), GINI index, overall level of unemployment (\%), 25-29 years old unemployment (\%) and higher education enrolment (ISCED 6 to 8). Considering that macroeconomic change could not be automatically transformed into deprivation and grievance, I further analyse economic situation in detail, describing economic context for each fieldwork period of ESS. 
Viktoriia Muliavka, Political Participation and Institutional Trust of Young Adults in Ukraine: Matching Economic and Political Conditions with European Social Survey Fieldwork Periods, 2004-2012

Ukrainian economy had experienced one of the world's largest economic downturns after the deployment of a new round of financial and economic crisis in 2008. In 2009 Ukrainian GDP per capita growth had reached its critical negative point (-14.4\%) (Table 2). General level of unemployment had increased to $9.6 \%$ in 2009. Starting from 2009 the level of youth unemployment remained substantially higher than overall statistics and higher education enrolment had been declining since 2008 that potentially makes this category of society more perceptional to grievance.

Table 2. Socio-economic indicators in percent

\begin{tabular}{lcccccccccc}
\hline Indicator & 2004 & 2005 & 2006 & 2007 & 2008 & 2009 & 2010 & 2011 & 2012 & 2013 \\
\hline $\begin{array}{l}\text { GDP per capita growth } \\
\text { (annual \%) }\end{array}$ & 12.9 & 3.46 & 8.03 & 8.55 & 2.86 & -14.42 & 4.61 & 5.85 & 0.49 & 0.20 \\
GINI Index & 29 & 29 & 29.8 & 27 & 26.6 & 25.3 & 24.8 & 24.5 & 24.7 & 24.5 \\
$\begin{array}{l}\text { Overall unemployment } \\
\text { (\%) }\end{array}$ & 9.2 & 7.8 & 7.4 & 6.9 & 6.4 & 9.6 & 8.8 & 8.6 & 8.1 & 7.7 \\
$\begin{array}{l}\text { 25-29 years old } \\
\text { unemployment (\%) }\end{array}$ & 9.3 & 7.6 & 7.3 & 6.9 & 7.0 & 10.4 & 9.9 & 9.2 & 9.5 & 8.7 \\
$\begin{array}{l}\text { Higher education } \\
\text { enrollment } \\
\text { (ISCED 6 to 8) }\end{array}$ & 69,6 & 75,1 & 78,7 & 81,1 & 79,2 & 77,8 & 74,9 & 64,7 & 65,0 & 69,6 \\
\hline
\end{tabular}

Note: Data from World Bank Data (GDP per capita growth; GINI Index; Higher education enrollment) and State Statistics Service of Ukraine (25-29 years old unemployment)

a Data about higher education enrollment is calculated as total enrolment in higher education (ISCED 6 to 8) of the five-year age group following on from secondary school leaving.

In further sections I provide description of potential sources of socio-economic grievance per each period of ESS. I analyze statistical data and available literature that provides details on socio-economic context of youth during 2004-2013 time period. The analyses suggest that there were potential grievances during 2009 economic crises. However, the mass political mobilization during 2004 Orange Revolution also had its socio-economic roots in illegal privatization and corruption, unbalanced economic development and growing geographic disparities in income.

Economy: 2004-2005

After prolonged recession in 1990s, Ukrainian economy started its positive growth only in 1999 and in 2004 had reached the highest rates of GDP per capita growth in post-socialist period. According to GINI Index, inequality in distribution of income among households had declined from $39.3 \%$ in 1995 to $29 \%$ in 2004 
2005. Poverty headcount ratio at $\$ 1.90$ a day (2011 PPP) (\% of population) had also declined from 5.4\% in 1995 to $0.6 \%$ in 2004 (World Bank Data).

The unemployment situation for Ukrainians before the first ESS fieldwork period of late winter 2005 was in a period of decreases. In 2000-2004 the number of unemployed had decreased from $12.4 \%$ to $9.2 \%$ of economically active population (7.8\% in 2005). The number of unemployed in 2004 between youth cohorts was 9.3\% for 25-29 year olds (in 2005 it further decreased to 7.6\%). (State Statistics Service of Ukraine).

At the beginning of 2000s the Ukrainian economy had experienced important economic transformations that could have contributed to the Orange Revolution in November 2004-January 2005. First, big enterprises were denationalised in 2003-2004 and went to regime insiders. A wave of 'illegal and covert privatisation of production facilities, research institutes, communal housing trade outlets and natural resources that developed on the eve of the 2004 presidential election and carried on right up to the final round of voting followed' (Bojcun 2011). Second, the processes of unregulated expansion of the exporting sectors became one of the reasons for the socio-political crisis in Ukraine at the end of 2004 and was the direct result of chronic ineffectiveness of the socio-economic strategy of sustainable development (Zhalilo 2009). Third, big enterprises avoided their tax obligations through corrupt agreements between firms and regional taxation authorities that lead to concentration of capital in certain 'oligarchic clans' connected with political elites (Bojcun 2011). Finally, by October 2004, regional disparities in mean income had reached its critical point (700 hryvnias per month in Eastern regions and 400 hryvnias per month in Western regions) that could explain why more rural and urban workers from the Central and Western regions tended to support the Orange camp (Viktor Yushchenko), and the industrial workers of Eastern and Southern Ukraine supported the camp of Viktor Yanukovych during Orange revolution (Mykhnenko 2009). According to Bojcun (2016), writing for the Commons Journal, ${ }^{[1]}$ 'The mounting social and regional economic inequalities and an increasingly repressive regime were the triggers for the 2004 Orange Revolution'. By 2005 there was a decline in GDP per capita from 12.9 percent to 3.4 percent (Bojcun 2011).

During 1990-2005, the number of students in Ukrainian universities had increased from 170 to 466 per 10 thousands of people (Oksamytna 2010, 166). Also, during this time period, the number of higher educational institutions had increased from 891 to 966 . Higher education was expanding predominantly through the emergence and development of the private sector. After the collapse of socialist block, 126 private universities were created (State Statistics Service of Ukraine). In addition to private universities, public ones had started to provide fee-based services. 
Viktoriia Muliavka, Political Participation and Institutional Trust of Young Adults in Ukraine: Matching Economic and Political Conditions with European Social Survey Fieldwork

Periods, 2004-2012

\section{Economy: 2006-2007}

ESS Ukraine 2006 was actually collected in the end of that year (December) and into early 2007, a period of rising economic growth. Comparing to 2005, GDP per capita growth had increased from 3.4 to 8 percent in 2006 and reached 8.5 percent in 2007. At that point Ukraine had experienced eight years of GDP growth from the beginning of 2000 to the end of 2007 (Bojcun 2011).

In 2007 a sign of economic overheating was already appearing as commercial banks took larger amounts of short-term foreign credits to pass on as loans. Foreign direct investments in Ukraine rose sharply from a \$1.7 billion net inflow in 2004 to $\$ 9.2$ billion in 2007. At the end of 2007 the National Bank of Ukraine responded to overheating by limiting the short-term loans commercial banks could take from abroad (Bojcun 2011).

ESS respondents saw an extended period of decreasing unemployment. The number of the unemployed of all ages continued to decrease from $7.8 \%$ in 2005 to $7.4 \%$ in 2006 and $6.9 \%$ in 2007 . For youth (25-29 years old) unemployment had decreased at about the same percent. However, the share of unemployed after graduation from secondary and higher education institutions in general number of unemployed had increased in one point (from $16.3 \%$ in 2005 to $17.4 \%$ in 2007). Real average monthly salary for all ages comparing to previous year had decreased from $120.3 \%$ in 2005 to $118.3 \%$ in 2006 and $112.5 \%$ in 2007 (State Statistics Service of Ukraine).

The number of students in 2006/2007 had increased to 2.7 million people comparing to 2004/2005 (2.6 million people), when the number of higher educational institutions had decreased from 966 to 951 (State Statistics Service of Ukraine). Generally, government expenditure on education, expressed as percent of total government expenditure, had increased slightly from $12.8 \%$ in 2004 to $14 \%$ in 2007 . However, government expenditure per tertiary student (expressed as percent of GDP per capita) in 2006 had remained stable comparing to previous year (32.3\%), and in 2007 had decreased to 30.5\% (World Bank Data).

\section{Economy: 2008-2009}

ESS Ukraine fieldwork for 2008 was actually in the first month of Spring 2009, when the Ukrainian economy had experienced 'one of the world's largest economic downturns' (Kravchuk 2015: 5). GDP per capita growth had fallen from 8.5 percent in 2007 to 2.8 percent in 2008 and in 2009 had reached its critical negative point (-14.4 percent). The annual decrease in GDP in 2009 was 15.1 percent (World Bank Data). The share of foreign capital in Ukraine's banks grew from 13 percent in 2004 to over 50 percent in 2009, but as Bojcun (2011) emphasizes foreign capital did not go into technologically upgrading 
and diversifying the economy, except in a very limited way. By April 2009 seven of the largest ten banks were foreign-owned. According to Bojcun (2011), by 2008 Russian private investors occupied commanding positions in non-ferrous metallurgy, petroleum refining and petrochemicals and mobile telecommunication, and had strong positions in iron, steel and the dairy industry as well as financial sector. From August 2008 the collapse of Ukraine's foreign trade and the seizure of its banking system prompted massive capital outflows, leaving net FDI at $\$ 6.2$ billion for the year as a whole. Crises deepened in the fourth quarter of 2008 and there was no domestic demand to replace it. As the result, Ukrainian economy had experienced stagflation: from September 2008 the hryvnia steadily devalued (Bojcun 2011).

The government's response to the crisis in 2009 can be summarised as follows: The Cabinet led by Yulia Tymoshenko, and supported by the President Yushchenko, took the IMF loan and made it the key point of its strategy to combat the impact of the financial crises on the economy and state finances. The failure of Tymoshenko's government to deal adequately with the crisis during 2009 contributed to her defeat in the 2010 presidential elections (Bojcun 2011).

Preparation of the 2009 state budget showed a shortfall of approximately $\$ 17$ billion in meeting social welfare payments (Bojcun 2011). Sharp economic downturn had other consequences: growing indefinite layoffs and unemployment reaching 9.6 percent in 2009, mounting wage arrears, deepening household indebtedness and persistent price inflation of essential consumer goods (Bojcun 2011).

Young people suffered heavily from the economic crisis. According to government statistics, for the 25-29 age cohort unemployment reached $10.4 \%$ in 2009. The share of unemployed after graduation from secondary and higher education institutions in general number of unemployed had increased to $18.3 \%$ in 2008, but in 2009 it decreased to $14.1 \%$ (State Statistics Service of Ukraine).

During the economic crisis, the number of students in 2008/2009 had increased from 2.6 to 2.8 million, though the number of universities decreased from 951 in 2006/2007 to 904 in 2008/2009 (State Statistics Service of Ukraine). In 2008, government expenditure on education expressed as percent of total government expenditure) had slightly decreased to $13.6 \%$. In 2009 , it had reached $15 \%$, which was the highest point during post-socialist period.

From 2007 to 2009 the government increased its expenditures per tertiary student (expressed as percent of GDP per capita) from 30.5 percent in 2007 to 39 percent in 2009 (World Bank Data). This relative increase in expenditures helped to neutralize negative consequences of economic crises for students, however it does not indicate improvement in real socio-economic conditions of youth considering negative GDP growth in 2009. 
Viktoriia Muliavka, Political Participation and Institutional Trust of Young Adults in Ukraine: Matching Economic and Political Conditions with European Social Survey Fieldwork Periods, 2004-2012

\section{Economy: 2010-2011}

ESS Ukraine 2010 was actually fielded in late summer 2011, in which respondents saw a slow rising economy but rising government debt. In 2010-2011 GDP per capita growth had increased to $4.6 \%$ in 2010 and 5.8\% in 2011 (World Bank Data). Accumulation of international loans in 2009-2010 had led to a threatening situation in 2011, when Ukrainian state debt reached $\$ 59.2$ bln (comparing to $\$ 24.6$ bln in 2008). What is more, in 2010 Ukrainian budget had experienced significant deficit - the share of expenses coverage by income was only $83 \%$ (95\% in 2011) (Kravchuk 2015).

ESS respondents also saw small decreases in unemployment. General level of unemployment had decreased to $8.8 \%$ in 2010 and to $8.6 \%$ in 2011 . The level of youth unemployment reminded higher than average $(9.9 \%$ in 2010 and $9.2 \%$ in 2011) and the category of 'unemployed after graduation from secondary and higher education institutions' had increased its share in general number of unemployed during those years to $16.2 \%$ in 2010 and $18.7 \%$ in 2011 (State Statistics Service of Ukraine).

During this period, youth in Ukraine saw fewer students and fewer universities than in the previous period. In 2010/2011 the number of students started to decrease, reaching 2.5 million of people and the number of universities had furtherly decreased to 854 (State Statistics Service of Ukraine). Government expenditure on education ( $\%$ of government expenditure) had also decreased to $13.4 \%$ when government expenditures per tertiary student had decreased by $1 \%$ comparing to 2009 (World Bank Data).

\section{Economy: 2012-2013}

ESS Ukraine 2012 was actually in the middle of summer 2013; this would be the last ESS fieldwork in Ukraine for a long time. The economy was slow growing and government debt rose. GDP per capita growth had again decreased to $0.5 \%$ in 2012 and $0.2 \%$ in 2013 (World Bank Data). After 2009 the negative trade surplus increased annually, reaching a mark of $\$ 15$ billion in 2012. Ukrainian public debt increased to $\$ 64.5$ bln in 2012 and to $\$ 73.2$ bln in 2013 . The situation with deficit of Ukrainian budget also get worse. The share of expenses coverage by budget incomes had declined to $90 \%$ in 2012 and to $88 \%$ in 2013 (World Bank Data). ${ }^{[2]}$

The level of unemployment had decreased to $8.1 \%$ in 2012 and $7.7 \%$ in 2013 . Young people had remained more vulnerable category of society comparing to the average level of unemployment. For 25-29 age cohort the level of unemployment was $9.5 \%$ in 2012. In 2013 it had slightly decreased, but still reminded higher than the average level (8.7\%) (State Statistics Service of Ukraine). 
Students and universities decreased in number. In 2012-2013 the number of students had decreased to 2170.1 thousands of people and number of universities had decreased to 823 (State Statistics Service of Ukraine). Government expenditure on education ( $\%$ of government expenditure) had remained stable when government expenditures per tertiary student (\% of GDP per capita) had increased to $41.4 \%$ in 2012 and 43.8\% in 2013 (World Bank Data). In 2012 new law on budget reallocation in higher education was implemented, according to which the number of funded places were decreased for social sciences, law and business and increased for computer science and technical fields (Orlova 2013, 13).

\section{Youth Political Opportunity Structure by ESS Fieldwork Periods}

In this section I explore the political opportunity structure for youth political mobilization during ESS fieldwork periods. I focus on the interests in protest mobilization of main political players and parties and their actions towards youth. What constitutes a political opportunity structure is not widely shared, though there are some commonalities across studies (Meyer and Minkoff 2004). I focus somewhat narrowly on policies oriented on youth, youth political orientations, changes in the number of youth organizations, and specific events in youth activism.

I analyze the main protest events with participation of youth based on Ukrainian Protest and Coercion Data project organized by Center for Social and Labor Research. This project is a publicly available source of information about protest events in Ukraine. Ukrainian Protest and Coercion Data project database contain information about all protest events that have happened in Ukraine reported by Ukrainian web-media in 2010-2016, of which the research group selected more than 190 , regardless of their size and demands.

Among a number of indicators, the data includes the time (event start date, event end date, date of the week), place (oblast, region, location) and type of the events (preempt, rally, picket, search, negotiation, strike etc.), as well as information about participants (workers, pensioners, local authorities, citizens, teachers, students, small businesses etc.) and their demands (social-economic, ideological/ regional identity, political, civic rights. According to the website [https://cslr. org.ua/en/methodology/], the project was supported by National Endowment for Democracy and International Fund "Vidrodzhennya". Detailed information about methodology of Ukrainian Protest and Coercion Data project could be found in Ishchenko (2016) article.

In following sections I provide detailed description of political opportunity structure for youth mobilization for each ESS Ukraine fieldwork period. Descriptions are based on available statistical data, local surveys and protest event data. These data have limits, as some indicators such as the number of 
Viktoriia Muliavka, Political Participation and Institutional Trust of Young Adults in Ukraine: Matching Economic and Political Conditions with European Social Survey Fieldwork Periods, 2004-2012

youth organizations and student protest events are not comparable across time. The data do not include information about other possible sources of mobilization, such as changes to technological forces. The internet deserves a mention, however. According to World Bank data, percentage of individuals using Internet in Ukraine had substantially increased from 3.5 percent in 2014 to 40.9 percent in 2013. For youth, that are more engaged in using of Internet and social media, this developments in access to technology had created new space for getting information and political organization via social media as well as opened new opportunities for political parties and other political actors to use Internet as a mechanism for political mobilization or propaganda.

\section{Politics: 2004-2005}

Of all events that could have had an outsized impact on how all age groups in ESS Ukraine reported their political participation and their trust in institutions, the Orange Revolution was by far the largest and most important. The Orange Revolution was from late November 2004 to January 2005, and the ESS Ukraine fieldwork period was right on its heels, being from late January 2005 to midMarch, 2005.

Demonstrations started in the aftermath of the run-off vote of the 2004 presidential election that was eventually won by Viktor Yanukovych, the incumbent prime minister from the Party of Regions. As the result of political crises and mass protest events, the election was re-run in January 2005 and opposition leader Viktor Yushchenko was declared the President (Wilson 2009).

Both Orange forces (opposition political parties) and blue ones, which were for the Party of Regions, played a key role in the mobilization of youth protesters. Those under 30 years old were three times more likely to be politically engaged in Orange Revolution comparing to other age cohorts (Kuzio, 2006). Qualitative research by Tereshchenko (2010) suggests that youth 'conceptualizations of, and emotional and practical responses to, the Orange Revolution were interlinked with regional differences' (Tereshchenko 2010: 99-100). Young people from Western Ukraine were more engaged and active in oppositional protests of Orange Revolution comparing to youth from Eastern Ukraine that could be explained by regional disparities in voting preferences (Viktor Yushchenko had more support in the West, when Viktor Yanukovych in the East).

Politics: 2006-2007

ESS Ukraine was fielded in December, 2006 to January 2007, well after the March 2006 Ukrainian parliamentary elections. Following the Orange Revolution and 
2004 presidential elections, the Ukrainian parliament transferred some power from the president to the parliament. As the result of the elections, Party of Regions recieved 32.1 percent of votes, when Our Ukraine Bloc (party of current president Viktor Yushchenko) only 14 percent. The second largest party in parliament was the Yulia Tymoshenko Bloc that received 22.3 percent of votes.

After 2006 elections Party of Regions (PoR) received 186/450 votes and became the leading party in the parliament. PoR had their youth-wing organization since 2002. Considering their youth-oriented policies, party declared in their official program to support at least $75 \%$ budgeted places in higher educational institutions, a minimum-wage student stipend, a minimum $20 \%$ annual raise in educator salaries and universal Internet access. In labour policy, PoR declared to provide internships for students and support in finding the first job. ${ }^{[3]}$ However, those social promises had more declarative character as none of them were fully implemented during PoR government that could be one of the reasons of further distrust in the party.

Politics: 2008-2009

The ESS fieldwork period was March 2009 to April, 2009. Just before that, the number of youth and children organizations in Ukraine had increased (from 176 in 2007 to 200 in 2008 and 221 in 2009; see Libanova 2010). However, the share of those organizations in the total number of non-governmental organizations had been declining from $13.5 \%$ in 2005 to $12.9 \%$ in 2008 and $12.6 \%$ in 2009 (Libanova 2010).

In 2008 there were demonstrations (marches, protest assemblies and occupations) both for and against the idea of Ukraine being affiliated with NATO (Ortiz et al 2013). The PoR, long building its youth wing, supported demonstrations against NATO with thousands of participants. Joining PoR was the Communist Party of Ukraine. At the same time, some smaller marches for affiliation with NATO with young participants took place in Western regions of Ukraine. Those marches supported by Our Ukraine and Yulia Tymoshenko Bloc, whose representatives (President Viktor Yushchenko, Premier-minister Yulia Tymoshenko and head of Parliament Areseniy Yatseniuk) initiated a joint statement on the possibility of Ukraine joining the NATO Membership Action Plan. In autumn 2009 also began strikes against wage arrears and layoffs, and there were protest marches organised by the trade unions against poverty (Bojcun 2011). 
Viktoriia Muliavka, Political Participation and Institutional Trust of Young Adults in Ukraine: Matching Economic and Political Conditions with European Social Survey Fieldwork Periods, 2004-2012

Politics: 2010-2011

In this section I include the protest event data from the Ukrainian Protest and Coercion Data project that has data starting in 2009.

ESS Ukraine "2010" was actually fielded May 2011 to July 2011. There were several political events that could have had a distant influence on respondents' reports of their political participation and trust in institutions.

In January-February 2010 there were presidential elections in Ukraine. After the first round, competition between two candidates - opposition leader Viktor Yanukovych and prime minister Yulia Tymoshenko - had ended with the victory of Yanukovych. In both election rounds, both Yanukovych and Tymoshenko won around 20 percent of the youth vote (Balakireva 2010).

Compared with the election period, after the second round of the presidential election (February 2010), the number of protest events with student participants increased by nearly twice. The first increase in the number of student protests was in March. The Spring surge of protest activity is associated with the beginning of a series of actions against the appointment of Dmytro Tabachnyk as Minister of Education and Science of Ukraine (Korchak 2011). In the fall of 2010, student protests intensified, and one of the most common themes of these protests was the introduction of paid services in educational institutions (Korchak 2011). This intensification in student movement is not reflected in ESS data collected in 2011 as it does not show any raise in young people's participation in demonstrations during that time.

In addition, in 2010 public protests against attempts of employers to reduce their expenditures and increase the standard of labour exploitation, non-payment of wages, violation of collective agreements and factory closures became widespread (Bojcun 2011).

\section{Politics: 2012-2013}

Here, we should actually begin in October 2011, some months after ESS Ukraine "2010" fieldwork was completed and before ESS Ukraine 2012, which was actually in Summer 2013.

In October 2011, some months after the fieldwork of ESS in Ukraine was completed, there were series of student actions against 'anti-Ukrainian' position of Dmytro Tabachnyk in Kharkiv, Lugansk, Kyiv, Odesa and Khmelnitsky. One mass student protest was organised in October by students from Kyiv-Polytechnic University against what they argued was corrupt university rector elections (Ukrainian Protest and Coercion Data project database 2011).

At the same time, we can see activation of right-wing groups in dealing with youth problems. In October 2011 right-wing groups and organizations protested 
for provision of cheap apartments for young people in Kyiv and Khmelnitsky. In November 2011, in Ternopil the Youth Nationalist Congress held a theatrical performance on the same topic titled "Youth Housing for a freebie", when in Chernivtsi the police tried to prevent a nationalist organization's action held on the occasion of the Student's Day (Ukrainian Protest and Coercion Data project database 2011).

The 2012-2013 period could be characterised as radicalization of youth political participation from different ideological camps. For example, on January 20, 2012, people who presented themselves as a "youth wing" of the Party of Regions protested in Olexandria (Kropyvnytskyi Oblast). On January 29 in Kyiv, the police defended several hundred supporters of the all-Ukrainian union Svoboda (nationalist political party) from a few dozen anti-fascists and 27 young people who met the march of Svoboda with the slogans "Fascism will not pass!" were arrested in the city centre. The right wing continued its protest activities. In May 2012 two young men "armed" with forks, attacked a photo exhibition picturing the daily lives of LGBT families. In January 2013 two young people threw a smoke grenade into the room of the first floor of the Sumy State University, where students from African countries attended in large numbers. Moreover, there was an attack on trade union activists after their rally against the exploitation of students and raids on student film shows at universities (Ukrainian Protest and Coercion Data project database 2013).

A new project of law on higher education created by Dmytro Tabachnyk that was oriented on the expanding of paid services, produced a new wave of student protests in 2012-2013. Later, Dmytro Tabachnyk's project of law was replaced with one that was developed in dialogue with representatives of higher education institutions and the student movement (Ukrainian Protest and Coercion Data project database 2013).

In March 2012, a newly formed coalition of Svoboda, Front of Change, Fatherland and Udar political parties, along with local organizations, held a series of actions in the 14 regional centres and the city of Yenakievo directed against the incumbent president. The organizers of the protest named these actions, "Show the Red Card to Yanukovych". Despite that the campaign was announced in advance, and the unconditional relevance of social slogans, on average only 10-20 young right-wing people had participated in local protests.

In October 2012 the Ukrainian parliamentary election took place. According to the results of election, Party of Regions received 30 percent of votes, when Fatherland (including United Opposition) received 25.5 percent of votes. 
Viktoriia Muliavka, Political Participation and Institutional Trust of Young Adults in Ukraine: Matching Economic and Political Conditions with European Social Survey Fieldwork

Periods, 2004-2012

\section{TRENDS IN YOUTH POLITICAL PARTICIPATION AND TRUST IN INSTITUTIONS IN UKRAINE}

In this section I present trends in young adult political participation and trust in institutions for Ukraine in every wave of ESS in which Ukraine appears.

Using ESS, I measure political participation through: voted last national election; contacted politician or government official, worked in political party or action group, worked in another organization or association, worn or displayed campaign badge/sticker, signed petition, taken part in lawful public demonstration, boycotted certain products, non-electoral participation. For indicator of non-electoral participation all variables of political participation except voting were recoded as any type of non-electoral participation $=1$, otherwise $=0$.

Trust in Ukrainian political institutions is operationalised through the next indicators: trust in countries' parliament; trust in the legal system; trust in the police; trust in politicians; trust in political parties. Trust in international institutions is represented by indicators of trust in the European Union and trust in the United Nations. Percentage within indicators of trust in institution represents categories 6 to 10 of 11-point scale (where $0=$ no trust and $10=$ complete trust). Youth is defined as 18-29 years old.

The level of youth political participation is generally low across time with some exceptions in non-electoral participation in 2005 and voting in 2006 Ukrainian parliamentary election (Table 2). Such raise of non-electoral participation in 2005, particularly in taking part in lawful public demonstrations (28.4\%) and displaying campaign badge or sticker (23.6\%), is driven by Orange Revolution events in Ukraine during which youth were key social group participating in 2004-2005 protests and political events (Kuzio, 2006).

Table 3. Youth political participation in percent ( $\mathrm{n}$ in parentheses)

\begin{tabular}{lccccc}
\hline Form of Political Participation & 2005 & $2006 / 2007$ & 2009 & 2011 & $\mathbf{2 0 1 3}$ \\
\hline Voted last national election & $\mathbf{5 5 . 9}$ & $\mathbf{7 5 . 3}$ & $\mathbf{6 0 . 6}$ & $\mathbf{5 7 . 8}$ & $\mathbf{5 5 . 7}$ \\
& $(185)$ & $(272)$ & $(197)$ & $(171)$ & $(219)$ \\
Contacted politician or government official & $\mathbf{5 . 1}$ & $\mathbf{3 . 9}$ & $\mathbf{5 . 2}$ & $\mathbf{6 . 4}$ & $\mathbf{4 . 3}$ \\
& $(17)$ & $(14)$ & $(17)$ & $(19)$ & $(17)$ \\
Worked in political party or action group & $\mathbf{6}$ & $\mathbf{3 . 9}$ & $\mathbf{2 . 1}$ & $\mathbf{5 . 1}$ & $\mathbf{3}$ \\
& $(20)$ & $(14)$ & $(7)$ & $(15)$ & $(12)$ \\
Worked in another organization or association & 3.9 & 2.5 & $\mathbf{2 . 8}$ & $\mathbf{2}$ & $\mathbf{2 . 3}$ \\
& $(13)$ & $(9)$ & $(9)$ & $(6)$ & $(9)$
\end{tabular}




\begin{tabular}{lccccc} 
Worn or displayed campaign badge/sticker & $\mathbf{2 3 . 6}$ & $\mathbf{6 . 1}$ & $\mathbf{5 . 2}$ & $\mathbf{5 . 1}$ & $\mathbf{5 . 8}$ \\
& $(78)$ & $(22)$ & $(17)$ & $(15)$ & $(23)$ \\
Signed petition & $\mathbf{8 . 8}$ & $\mathbf{4 . 2}$ & $\mathbf{3 . 1}$ & $\mathbf{2 . 7}$ & $\mathbf{2 . 3}$ \\
& $(29)$ & $(15)$ & $(10)$ & $(8)$ & $(9)$ \\
Taken part in lawful public demonstration & 28.4 & $\mathbf{8}$ & $\mathbf{6 . 1}$ & $\mathbf{5 . 1}$ & $\mathbf{2 . 8}$ \\
& $(94)$ & $(29)$ & $(20)$ & $(15)$ & $(11)$ \\
Boycotted certain products & $\mathbf{3}$ & $\mathbf{1 . 1}$ & $\mathbf{0 . 9}$ & $\mathbf{2 . 4}$ & $\mathbf{0}$ \\
& $(10)$ & $(4)$ & $(3)$ & $(7)$ & $(0)$ \\
Non-electoral participation & 39 & $\mathbf{1 4 . 8}$ & $\mathbf{1 8 . 2}$ & $\mathbf{1 5 . 7}$ & $\mathbf{1 3 . 2}$ \\
& $(127)$ & $(53)$ & $(58)$ & $(46)$ & $(51)$ \\
\hline
\end{tabular}

The analyses in Table 3 suggest that the percentage of Ukrainian youth that voted last national elections is significantly lower that percentage within older groups. This trend is stable across time. The rates of youth non-electoral participation are not higher than older age cohorts (Table 4). Trust in parliament does not show substantial differences by age (Table 6), with a small exception of young people's lower rates of trust in 2005 .

Table 4. Voted last national elections by age in percent (n)

\begin{tabular}{lccccc}
\hline Age group & 2005 & $2006 / 2007$ & 2009 & 2011 & 2013 \\
\hline \multirow{2}{*}{$18-29$} & $\mathbf{5 5 . 9}$ & $\mathbf{7 5 . 3}$ & $\mathbf{6 0 . 6}$ & $\mathbf{5 7 . 8}$ & $\mathbf{5 5 . 7}$ \\
& $(158)$ & $(272)$ & $(197)$ & $(171)$ & $(219)$ \\
$30-45$ & $\mathbf{8 2 . 7}$ & $\mathbf{8 3 . 2}$ & $\mathbf{7 9 . 4}$ & $\mathbf{7 4 . 7}$ & $\mathbf{7 3 . 8}$ \\
& $(388)$ & $(272)$ & $(336)$ & $(337)$ & $(394)$ \\
$46-60$ & $\mathbf{8 5 . 4}$ & $\mathbf{9 3}$ & $\mathbf{8 7 . 1}$ & $\mathbf{8 4 . 6}$ & $\mathbf{8 1 . 9}$ \\
& $(415)$ & $(490)$ & $(432)$ & $(397)$ & $(431)$ \\
$61+$ & $\mathbf{8 7 . 7}$ & $\mathbf{9 0 . 7}$ & $\mathbf{8 6 . 1}$ & $\mathbf{8 7 . 3}$ & $\mathbf{8 6 . 2}$ \\
& $(612)$ & $(557)$ & $(477)$ & $(584)$ & $(573)$ \\
\hline
\end{tabular}

Table 5. Non-electoral participation by age in percent (n)

\begin{tabular}{lccccc}
\hline Age group & 2005 & $2006 / 2007$ & 2009 & 2011 & 2013 \\
\hline $18-29$ & 39 & 14.8 & 18.2 & 15.7 & 13.2 \\
& $(127)$ & $(53)$ & $(58)$ & $(46)$ & $(51)$ \\
$30-45$ & 35.8 & 22 & 19.4 & 13.8 & 18.3 \\
& $(166)$ & $(97)$ & $(80)$ & $(62)$ & $(97)$ \\
$46-60$ & 35.2 & 21.9 & 21.6 & 17.6 & 14.1 \\
& $(170)$ & $(113)$ & $(105)$ & $(82)$ & $(73)$ \\
$61+$ & & 16 & 17.6 & $15.5(103)$ & 13.3 \\
& $23.1(158)$ & $(96)$ & $(96)$ & & $(87)$ \\
\hline
\end{tabular}


Viktoriia Muliavka, Political Participation and Institutional Trust of Young Adults in Ukraine: Matching Economic and Political Conditions with European Social Survey Fieldwork Periods, 2004-2012

Table 6. Youth trust in institutions in percent (n)

\begin{tabular}{lccccc}
\hline Trust in... & 2005 & $2006 / 2007$ & 2009 & 2011 & 2013 \\
\hline \multirow{2}{*}{ Parliament } & 19 & 3.9 & $\mathbf{4}$ & 4.7 & $\mathbf{7 . 1}$ \\
& $(63)$ & $(14)$ & $(13)$ & $(14)$ & $(28)$ \\
Legal system & 19.9 & $\mathbf{8 . 6}$ & 7.4 & 7.4 & $\mathbf{9 . 9}$ \\
& $(66)$ & $(31)$ & $(24)$ & $(22)$ & $(39)$ \\
Police & 13.3 & 10 & 9.8 & 9.1 & $\mathbf{1 1 . 2}$ \\
& $(44)$ & $(36)$ & $(32)$ & $(27)$ & $(44)$ \\
Politicians & 9.4 & 3.6 & 0.9 & $\mathbf{3}$ & $\mathbf{5 . 8}$ \\
& $(31)$ & $(13)$ & $(3)$ & $(9)$ & $(23)$ \\
Political parties & 10.3 & 4.4 & 1.8 & 3 & 6.6 \\
& $(34)$ & $(16)$ & $(6)$ & $(9)$ & $(26)$ \\
European Union & $\mathbf{2 6 . 9}$ & $\mathbf{1 8 . 8}$ & $\mathbf{2 1 . 2}$ & $\mathbf{2 1 . 6}$ & $\mathbf{2 4 . 9}$ \\
& $(89)$ & $(68)$ & $(69)$ & $(64)$ & $(98)$ \\
United Nations & $\mathbf{2 7 . 5}$ & $\mathbf{1 8 . 3}$ & $\mathbf{1 7 . 8}$ & $\mathbf{2 2 . 3}$ & $\mathbf{2 2 . 4}$ \\
& $(91)$ & $(66)$ & $(58)$ & $(66)$ & $(88)$ \\
\hline
\end{tabular}

Table 7. Trust in parliament by age in percent (n)

\begin{tabular}{lccccc}
\hline Age group & 2005 & $2006 / 2007$ & 2009 & 2011 & 2013 \\
\hline \multirow{2}{*}{$18-29$} & 19 & 3.9 & 4 & 4.7 & 7.1 \\
& $(63)$ & $(14)$ & $(13)$ & $(14)$ & $(28)$ \\
$30-45$ & 26 & 3.8 & 3.3 & 2.7 & 5.4 \\
& $(122)$ & $(17)$ & $(14)$ & $(12)$ & $(29)$ \\
$46-60$ & 26.5 & 8.2 & 4.4 & 5.3 & 6.6 \\
& $(129)$ & $(43)$ & $(22)$ & $(25)$ & $(35)$ \\
$61+$ & 34.1 & 13 & 5.2 & 9.7 & 7.2 \\
& $(238)$ & $(80)$ & $(29)$ & $(65)$ & $(48)$ \\
\hline
\end{tabular}

As with political participation, youth trust in Ukrainian institutions is tremendously low across time. The exception is 2005, when trust in parliament and legal system had reached almost $20 \%$ and trust in politicians and political parties had reached around $10 \%$ (Table 6 ). Such relatively positive evaluations of political institutions in 2005 are most probably connected with youth satisfaction with shirt-term outcomes of Orange Revolution events. However, youth trust in parliament is lower comparing to older age cohorts across time (Table 7). Trust in international institutions ( $\mathrm{EU}$ and $\mathrm{UN}$ ) is noticeably higher than in Ukrainian ones. 


\section{CONCLUSION}

In this article I analysed the economic and political conditions of youth political participation and institutional trust in Ukraine in 2004-2013 and matched them to European Social Survey fieldwork dates. The purpose was to better understand trends the potential sources of economic grievance and possibilities for building political opportunity structure. Since the theories of economic grievance and political opportunity structure are often examined using survey data, and since the context of the fieldwork period should influence respondents' answers, I mapped these potential sources to the specific ESS fieldwork periods.

The full test of grievance theory is beyond the scope of this paper, but the evidence suggests that the periods of macro-level grievance indicators do not align with trends in political participation. As Figure 1 shows, economic downturn in 2009 did not have any substantial influence on voting or non-electoral participation.

Figure 1. Youth voting, non-electoral participation GDP growth and unemployment, percentage

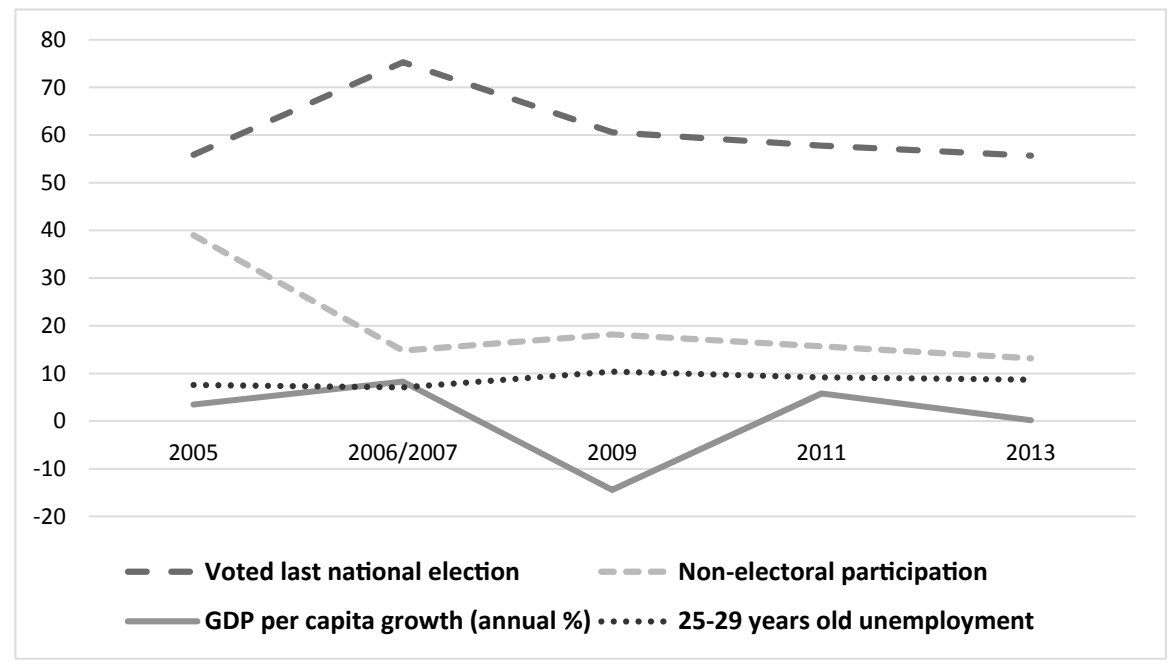

Note: Own calculations based on ESS 2004-2012, World Bank Data, State Statistics Service of Ukraine

General low level of youth political participation in Ukraine during post-socialist transformations is fairly expected in the context of neoliberal policies, from which youth suffered substantially in terms of access to labour market and students' living conditions. High rates of political participation in 2005 could be explained by macropolitical factors of mass protests mobilisation and building political 
Viktoriia Muliavka, Political Participation and Institutional Trust of Young Adults in Ukraine: Matching Economic and Political Conditions with European Social Survey Fieldwork Periods, 2004-2012

opportunity structure during rotation of political elites in Orange Revolution. In the context of substantial economic grievance, such mass mobilization was driven rather by political parties in their struggles for taking power and their need in wider political support than by grassroots movements. For instance, despite of development of student movement in 2010-2013, supported predominantly by youth organisations, general level of youth non-electoral political participation did not reach even close level to 2005. On the contrary, it continued to decrease according to ESS data (Table 3).

It is not easy to clearly and elegantly connect the above sources of grievance with youth political participation in Ukraine during the periods of ESS fieldworks. Some macro-economic indicators that had direct impact on youth were not immediately translated into strife. For instance, during 2008-2009 the level of youth unemployment was the highest after financial crises and thus the youth had appeared to be at their most deprived. At the same time, in 2004 and 2013 macroeconomic indicators were not dramatically declining, while the high-profile issues of failed domestic and international economic policies, corruption and uneven redistribution of income constituted a general context of substantial grievance which perhaps contributed to the mobilization of young protesters during the Orange Revolution and the events of Euromaidan.

\section{NOTES}

1 According to the website [https://commons.com.ua/en/p/pro-nas/] the Journal of social criticism 'Commons' is a Ukrainian left intellectual edition, founded in 2009.

2 According to Bojcun (2016), 'the Maidan arose in 2013, as it did in 2004, because the new Ukrainian ruling class failed to share state power democratically or to invest in the development of its own society'. The period of Euromaidan events is not covered by the fieldwork of ESS.

3 Party of Regions also wanted to fully subsidize employment of the disabled, orphans and single mothers and provide training to the unemployed for occupations with labour shortages.

\section{REFERENCES}

Albacete,G.G.(2014). Youngpeople 'spoliticalparticipationin WesternEurope: Continuity or generational change?. Springer. https://doi.org/10.1057/9781137341310

Balakireva O. M. (2010). Features of electoral behaviour during 2010 presidential elections / Балакірева, О. М. (2010). Особливості електоральної поведінки виборів під час президентських виборів 2010 р. Украйнський соизіум, (1), 11.

Bojcun, M. (2011). The Ukrainian Economy and the International Financial Crisis. Dale, Gareth (Hg.): First the Transition, then the Crash. Eastern Europe in the 2000s. London, 143-168. 
Bojcun M. (2016). The reasons of Ukrainian crisis. Commons Journal. Access: https:// commons.com.ua/en/prichini-ukrayinskoyi-krizi/

Böröcz, J. (2012). Notes on the Geopolitical Economy of Post-State-Socialism. Socialism Vanquished, Socialism Challenged: Eastern Europe and China (1989-2011).

Dalton, R., Van Sickle, A., \& Weldon, S. (2010). The individual-institutional nexus of protest behaviour. British Journal of Political Science, 40(1), 51-73. https://doi. org/10.1017/S000712340999038X

Delli Carpini, M. X. (2000). Gen. com: Youth, civic engagement, and the new information environment. Political communication, 17(4), 341-349. https://doi. org/10.1080/10584600050178942

Earl, J., Maher, T. V., \& Elliott, T.(2017). Youth, activism, and socialmovements. Sociology Compass, 11(4). https://doi.org/10.1111/soc4.12465

Fisher, D. R. (2012). Youth political participation: Bridging activism and electoral politics. Annual Review of Sociology, 38, 119-137. https://doi.org/10.1146/annurevsoc-071811-145439

Gamson, W. A. (1968). Power and Discontent. Homewood: Dorsey Press.

Golovenko V. \& Zinchenko A. (2006) Public structures of the modern youth movement of Ukraine: the state and main tendencies. / Головенько, В. А., \& Зінченко, А. Г. (2006). Громадські структури сучасного молодіжного руху України: стан та основні тенденції. Український соціум, (2), 78-88.

Gurr, T. (1968). A causal model of civil strife: A comparative analysis using new indices. American political science review, 62(4), 1104-1124. https://doi.org/10.2307/1953907

Hart, J., \& Henn, M. (2017). Neoliberalism and the Unfolding Patterns of Young People's Political Engagement and Political Participation in Contemporary Britain. Societies, 7(4), 33. https://doi.org/10.3390/soc7040033

Hooghe, M., \& Kern, A. (2015). Party membership and closeness and the development of trust in political institutions: An analysis of the European Social Survey, 20022010. Party Politics, 21(6), 944-956. https://doi.org/10.1177/1354068813509519

Ishchenko, V. (2016). Far right participation in the Ukrainian Maidan protests: an attempt of systematic estimation. European Politics and Society, 17(4), 453-472. https://doi.org/10.1080/23745118.2016.1154646

Karakoc, Ekrem 2013 Economic inequality and its asymmetric effect on civic engagement: evidence from post-communist countries European Political Science Review / Volume 5 / Issue 02 /, pp 197-223

Korchak D. (2011). Student Protests / Корчак Д. (2011) Студентські протести. Протести, перемоги і репресії в Україні: результати моніторингу, жовтень 2009 - вересень 2010. /За ред. В. Іщенка. - К.: Центр дослідження суспільства, 2011. - 64 с.

Kravchuk O. (2015) Alternative mechanisms for the socio-economic development of Ukraine. Ed. Kravchuk Oleksandr - Kyiv: Center for Social and Labor Research, 2015

Kuzio, T. (2006). Ukraine is not Russia: Comparing youth political activism. SAIS Review of International Affairs, 26(2), 67-83. https://doi.org/10.1353/sais.2006.0035 Libanova E. (2010) Youth and Youth Policy in Ukraine: Socio-Demographic Aspects / Лібанова, Е. М. (2010). Молодь та молодіжна політика в Україні: соціальнодемографічні аспекти. К.: Інститут демографії та соичіальних досліджень ім. МВ Птухи НАН України. 
Viktoriia Muliavka, Political Participation and Institutional Trust of Young Adults in Ukraine: Matching Economic and Political Conditions with European Social Survey Fieldwork Periods, 2004-2012

Malysh L., Vynogradov O. (2010) The class status of youth on the labor market / Малиш Л., Виноградов О. Класовий статус молоді на ринку праці. Оксамитна, С., Виноградов, О., Малиш, Л., \& Марценюк, Т. (2010). Молодь України: від освіти до праці. К.: ВПЦ НаУКМА.-2010.-202 с.

Mamonova, V. \& Vasiliev, (2010). On the mechanism of financing of the state youth policy / Мамонова, В. В., \& Васильєв, А. О. (2010). Щодо механізму фінансування державної молодіжної політики. Теорія та практика державного управління, (1), 132-138.

Marien, S., Hooghe, M., \& Quintelier, E. (2010). Inequalities in non-institutionalised forms of political participation: A multi-level analysis of 25 countries. Political Studies, 58(1), 187-213. https://doi.org/10.1111/j.1467-9248.2009.00801.x

McFarland, D. A., \& Thomas, R. J. (2006). Bowling young: How youth voluntary associations influence adult political participation. American sociological review, 71(3), 401-425. https://doi.org/10.1177/000312240607100303

Melo, D. F., \& Stockemer, D. (2014). Age and political participation in Germany, France and the UK: A comparative analysis. Comparative European Politics, 12(1), 33-53. https://doi.org/10.1057/cep.2012.31

Meyer, D. S. (2004). Protest and political opportunities. Annu. Rev. Sociol., 30, 125-145. https://doi.org/10.1146/annurev.soc.30.012703.110545

Meyer, D. S., \& Minkoff, D. C. (2004). Conceptualizing political opportunity. Social forces, 82(4), 1457-1492. https://doi.org/10.1353/sof.2004.0082

Meyer, D. S., \& Staggenborg, S. (1996). Movements, countermovements, and the structure of political opportunity. American Journal of Sociology, 101(6), 1628-1660. https://doi.org/10.1086/230869

Mykhnenko, V. (2009). Class voting and the Orange Revolution: A Cultural Political Economy Perspective on Ukraine's Electoral Geography. In: Journal of Communist Studies and Transition Politics, Vol. 25, Nos. 2-3, June-September 2009. https://doi. org/10.1080/13523270902860626

Oksamytna S. (2010). Educational inequality and intergenerational educational mobility / Оксамитна С. Освітня нерівність і міжгенераційна освітня мобільність. Оксамитна, С., Виноградов, О., Малиш, Л., \& Марценюк, Т. (2010). Молодь України: від освіти до праці. К.: ВПЦ НаУКМА.-2010.-202 с.

Orlova, I. (2013). Education reform in Ukraine. The project "Popular Economy: Monitoring Reforms, (8), 17. / Орлова, I. (2013). Реформа освіти в Україні. Проект «Популярна економіка: моніторинг реформ, (8), 17.

Ortiz, I., Burke, S., Berrada, M., \& Cortés, H. (2013). World Protests 2006-2013.

Pehlivanova, P. (2009). The Decline of Trust in Post-communist Societies: The Case of Bulgaria and Russia. Contemporary Issues/Suvremene Teme, 2(1).

Quintelier, E. (2008). Who is politically active: The athlete, the scout member or the environmentalactivist?Youngpeople, voluntary engagementand political participation. Acta sociologica, 51(4), 355-370. https://doi.org/10.1177/0001699308097378

Rossi, F. M. (2009). Youth political participation: Is this the end of generational cleavage? International Sociology, 24(4), 467-497. https://doi.org/10.1177/0268580909334498 Simonchuk E. (2006). Working class in Ukraine: trends of structure recomposition / Симончук, Е. (2015). Рабочий класс в Украине: тренды рекомпозиции структуры. Социология: теория, методы, маркетинг. 
Smith, E. S. (1999). The effects of investments in the social capital of youth on political and civic behavior in young adulthood: A longitudinal analysis. Political psychology, 20(3), 553-580. https://doi.org/10.1111/0162-895X.00156

Solt, F. (2015). Economic inequality and nonviolent protest. Social Science Quarterly, 96(5), 1314-1327. https://doi.org/10.1111/ssqu.12198

Teorell, J., Torcal, M., \& Montero, J. R. (2007). 13 Political participation. Citizenship and involvement in European democracies: A comparative analysis, 334.

Tereshchenko, A. (2010). Ukrainian youth and civic engagement: unconventional participation in local spaces. Journal of youth studies, 13(5), 597-613. https://doi.or $\mathrm{g} / 10.1080 / 13676261.2010 .487518$

Tomescu-Dubrow, I., \& Slomczynski, K. M. (2016). Harmonization of cross-national survey projects on political behavior: developing the analytic framework of survey data recycling. International Journal of Sociology, 46(1), 58-72. https://doi.org/10. 1080/00207659.2016.1130424

Vráblíková, K. (2014). How context matters? Mobilization, political opportunity structures, and nonelectoral political participation in old and new democracies. Comparative Political Studies, 47(2), 203-229. https://doi.org/10.1177/0010414013488538

Wilkes, R. (2004). First Nation Politics: Deprivation, Resources, and Participation in Collective Action. Sociological Inquiry, 74(4), 570-89. https://doi.org/10.1111/ j.1475-682X.2004.00105.x

Wilson A. (2009). Ukraine's 'Orange Revolution' of 2004: The Paradoxes of Negotiation, in Adam Roberts and Timothy Garton Ash (eds.), Civil Resistance and Power Politics: The Experience of Non-violent Action from Gandhi to the Present, Oxford University Press, pp. 295-316

Zhalilo (2009). Theory and practice of electoral economic strategy of the state formation. / Жаліло (2009). Теорія $і$ практика формування елективної економічної стратегії держави, 125-31. 